\title{
A new genus and species of axiid shrimp (Crustacea, Decapoda) from a southwestern Indian Ocean seamount
}

\author{
Peter C. DWORSCHAK \\ Dritte Zoologische Abteilung, Naturhistorisches Museum Wien, A 1010 Vienna, Austria. \\ Email: Peter.Dworschak@nhm-wien.ac.at \\ urn:Isid:zoobank.org:author:4BCD9429-46AF-4BDA-BE4B-439EE6ADC657
}

\begin{abstract}
A new genus and species of axiid shrimp, Montanaxius mediumquod gen. et sp. nov., is described and illustrated based on three specimens collected from hexactinellid sponges from a seamount in the southwest Indian Ocean. The new genus is characterized by a laterally denticulate rostrum, short lateral carina, absence of submedian carina, a prominent toothed median carina, round pleomere pleura 2-5, pleurobranchs on second to fourth pereopods, and the presence of a male first pleopod and appendix interna on pleopods 3-5. It most closely resembles Levantocaris Galil \& Clark, 1993 and Planaxius Komai \& Tachikawa, 2008, but differs from the former by being gonochoristic, having a strongly elevated gastric region and well-developed eyes, and from the latter by its toothed median carina and the presence of a median telson spine.
\end{abstract}

Keywords. Montanaxius mediumquod gen. et sp. nov., Axiidae, seamount, sponge associate.

Dworschak P.C. 2016. A new genus and species of axiid shrimp (Crustacea, Decapoda) from a southwestern Indian Ocean seamount. European Journal of Taxonomy 229: 1-11. http://dx.doi.org/10.5852/ejt.2016.229

\section{Introduction}

During the IUCN Seamounts expedition, extensive samples were taken on board the RRS 'James Cook' from 7 November to 21 December 2011 from underwater mountains in the southwestern Indian Ocean (Rogers \& Taylor 2012; IUCN 2013). Sponges were one of the most frequent benthic organisms recorded on these seamounts. Several hexactinellid sponges were inhabited by associated caridean, stenopodidean and axiidean shrimps. One of these shrimps has been described recently as a new species of the hippolytid genus Paralebbeus Bruce \& Chace, 1986 by Komai (2013). The "glass shrimps" (Rogers \& Taylor 2012: figs 53-54) belong to the genus Spongiocaris Bruce \& Baba, 1973 and have recently been described as a new species (Komai et al. 2016). The axiid shrimps from the seamount

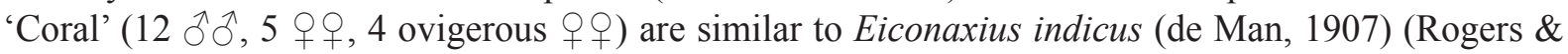
Taylor 2012: fig. 48). Three specimens ( $1 \hat{\delta}$ and 2 우) collected at the seamount 'Middle of What' could not be assigned to any of the axiid genera. The present paper describes them as a new species and erects a new genus for it. 


\section{Material and methods}

Host sponges were collected with a manipulator installed on the ROV 'KIEL 6000' during a dive on 1 Dec. 2011 at the 'Middle of What' seamount in the southwestern Indian Ocean during the 66th voyage of the RRS 'James Cook'. Shrimps were photographed alive on board in cold-water aquaria and later fixed in ethanol or formaldehyde (Rogers \& Taylor 2012: 60, 106).

All drawings were made using a camera lucida mounted on a stereo microscope, digitized and then inked and composed in Adobe Illustrator (Coleman 2003, 2009). Digital photographs were taken with a Nikon 995 camera mounted on a stereo microscope or a compound microscope. Stacks of several frames of different focal planes were fused using CombineZ5 (Haug et al. 2011).

The types have been deposited at the Naturhistorisches Museum Wien, Austria (NHMW). Size (in mm) is given as total length (TL) and carapace length (CL) in the form (TL/CL). Other abbreviations include: A1 = antennule; A2 = antenna; Mxp1-3 = first to third maxilliped; P1-P5 = first to fifth pereopod; Plp1Plp5 = first to fifth pleopod; fen = field collection number.

Terminology for the orientation of the limbs follows Poore (1997), where "upper" is used to describe the extensor (or anatomically anterior) margin and "lower" the flexor (or posterior) margin.

\section{Results}

Class Malacostraca Latreille, 1802

Order Decapoda Latreille, 1802

Infraorder Axiidea de Saint Laurent, 1979

Family Axiidae Huxley, 1879

\section{Montanaxius gen. nov. urn:1sid:zoobank.org:act:DF6AE674-18CA-46C1-B139-292865692B6B}

\section{Type species}

Montanaxius mediumquod gen. et sp. nov. by monotypy and present designation.

\section{Diagnosis}

Gonochoristic. Carapace smooth; cervical groove visible laterally almost to anterolateral margin. Rostrum triangular, broad, laterally denticulate, longer than eyestalks, depressed below level of carapace, continuous with definite lateral carinae; supraocular spines not differentiated from other spines; lateral carina short, unarmed; submedian carina absent; median carina a spinose ridge; postcervical carina absent. Pleomere 1 pleuron triangular, ventrally rounded; pleuron 2 broad, anteriorly and posteriorly rounded; pleura 3-5 posteriorly rounded. Eyestalk cylindrical, articulating; cornea pigmented. Antennal scaphocerite well developed. Mxp3 exopod not clearly bent at base of flagellum. Pleurobranchs present above P2-4; podobranchs and arthrobranchs well developed; epipods present on Mxp2 to P4. P1 slightly asymmetrical; merus with spines on lower border; propodus flattened; carpus-dactylus upper and lower margins smooth. P3-5 propodi with transverse rows of robust setae; dactyli tapering, with longitudinal rows of robust setae. Plp1 of male present. Plp2 of male with appendix masculina. Plp3-5 with appendix interna. Uropodal exopod with transverse suture. Telson with lateral spines and posterolateral robust setae; apex truncate-rounded, with median spine.

\section{Etymology}

The name is a combination of the stem of montanus (Latin for 'mountain', referring to the seamount where it was found) combined with Axius. The gender is masculine, as in Axius. 


\title{
Remarks
}

See discussion below.

\author{
Montanaxius mediumquod gen. et sp. nov. \\ urn:Isid:zoobank.org:act:3758B050-140A-49A8-81A9-240DDFA486A6
}

Figs 1-4

Eiconaxius sp. - Stone 2012: 74 (colour figure) (photograph by David Shale, available from http://ngm. nationalgeographic.com/2012/09/seamounts/img/image-02.jpg [accessed 19 Feb. 2016]).

\section{Etymology}

The specific epithet mediumquod is an arbitrary combination of the Latin words "medium", meaning middle, and "quod", meaning what, derived from the type locality 'Middle of What'; the name is used as a noun in apposition.

\section{Material examined}

\section{Holotype}

SOUTHWESTERN INDIAN OCEAN: ${ }^{\wedge}$, seamount 'Middle of What', 3757.915' S, 50²4.426' E, 1135 m depth, from hexactinellid sponge, coll. 1 Dec. 2011 (fcn: JC066-3498, parent\# 2584) (23.3/7.6) (NHMW 25677).

\section{Paratypes}

SOUTHWESTERN INDIAN OCEAN: 1 , same data as holotype (23.8/7.6) (NHMW 25676); 1 , same data as holotype, rostrum damaged, minor P1 missing, dissected (25.7/7.4) (NHMW 25675).

\section{Description}

Rostrum straight, depressed below level of carapace, 0.37 times length of front-to-cervical groove, with 3 to 4 lateral spines, posteriormost in supraocular position, but not enlarged, continuing into short unarmed lateral carina on anterior carapace. Submedian carina absent. High median carina with two strong teeth and one low tubercle reaching almost to cervical groove. Cervical groove distinct (Figs 1A-B, 2A, $3 \mathrm{~A}-\mathrm{B}, 4 \mathrm{~A}-\mathrm{B}$ ). No median carina posterior to cervical groove. Sternite 7 (pereopod 4) deeply divided in midline over posterior two-thirds and with sharp oblique lateral ridge (Figs 1F, 2H, 3L). Sternite 8 (pereopod 5) with setose triangular flap on anterior face at base of leg. Pleomere pleuron 11.5 times as high as middorsal length, ventrally rounded; pleuron 2 broad, lateral length 1.6 times dorsal length, anteriorly rounded, posteriorly rounded; pleura 3-5 ventrally rounded; pleuron 6 rounded (Fig 2B).

Eyestalks half as long as rostrum; cornea pigmented (Fig. 2C). Antennular peduncle reaching to middle of antennal article 4; basal article with lateral spine (Fig. 2D). Antennal article 2 with strong dorsolateral spine and small ventromesial spine; antennal acicle triangular, reaching to $1 / 3$ length of penultimate article of antennal peduncle, mesial margin with strong spine (Fig. 2E).

Mouthparts similar to those of other species of the family, without specific characters (see Poore \& Collins 2009). Third maxilliped (Fig. 2F-G) with ventral spine on coxa and basis, small spines on ischium lower border, prominent crista dentata; two strong spines on merus proximally, one spine on carpus lower border proximally; exopod as long as ischium-merus, flagellate distally.

First pereopods (chelipeds) significantly differentiated, major more swollen, with longer palm and shorter, more robust dactylus. Major cheliped on the right side in holotype (Fig. 1D) and paratype NHMW 25675, on the left side in the other female paratype (Fig. 3C); ischium as long as wide, one 
spine proximally on lower border; merus three times as long as high, three spines increasing in size on lower border, one subterminal spine on upper border; carpus short, $1 / 3$ length of merus, cup-shaped, unarmed; propodus with palm as long as merus, upper and lower borders smooth, curved, lower border with strong keel; small gap proximally between fingers when closed; fixed finger triangular, cutting edge with one strong triangular tooth at midlength and several smaller teeth distally, one large rounded tooth at $2 / 3$ length mesially; dactylus with incision proximally, upper border strongly curved, cutting edge with low triangular blade at midlength, one corneous spine on upper border near tip (Fig. 3D).

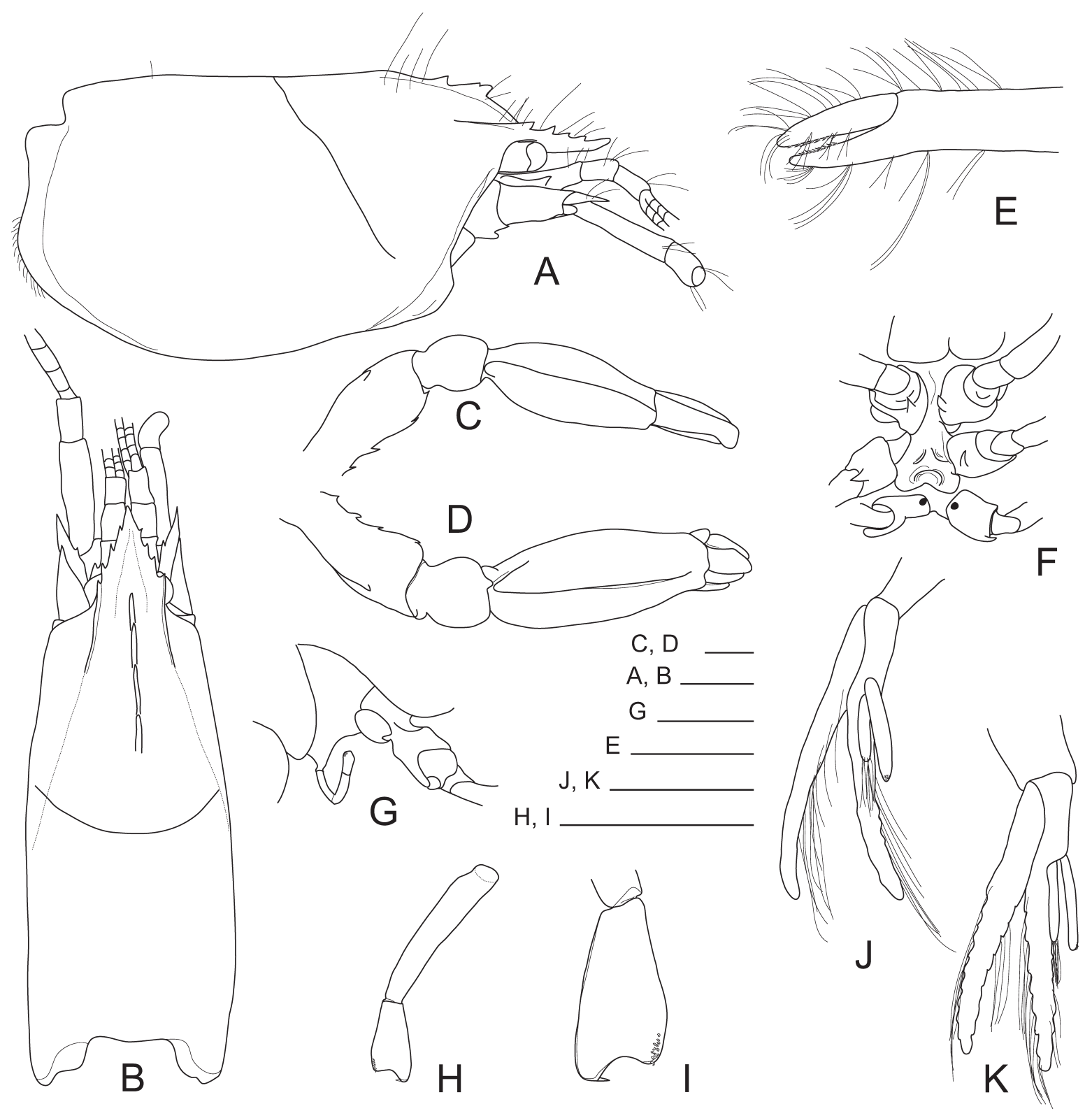

Fig. 1. Montanaxius mediumquod gen. et sp. nov., holotype, $\widehat{\jmath}$, NHMW 25677. A. Carapace in lateral view. B. Same, dorsal view. C. Minor cheliped in dorsal view. D. Major cheliped in dorsal view. E. Tip of pereopod 2. F. Sternites 6-8. G. Ventral part of coxa 5 and pleomere 1 with Plp1 (first article bent) in lateral view. H. Left Plp1 in anterior view. I. Terminus of left Plp1, posterior view. J. Left Plp2, mesial view. K. Right Plp2, anterior view. Setation omitted in C and D. Scale bars: A-H, J-K $=1 \mathrm{~mm}$; $\mathrm{I}=$ $500 \mu \mathrm{m}$. 
Minor cheliped (Figs 1C, 3E) slightly thinner and shorter than major one; ischium as long as wide, one spine proximally on lower border; merus with four spines on lower border and one subterminal spine on upper border; carpus short, cup-shaped; propodus with curved borders, unarmed, keel on lower border reaching to beginning of fixed finger, short keel on upper border distally; no gap between fingers when closed; fixed finger triangular, with almost straight cutting edge and corneous tip; dactylus slightly curved on upper border, almost straight on lower border, one corneous spine on upper border near tip (Fig. 3F).

Second pereopod (Fig. 3G) slender, 0.84 times as long as first pereopods; ischium short, merus long, five times as long as ischium, 8.3 times as long as wide; carpus 0.6 times length of merus; palm same length as carpus, fingers half as long as palm, cutting edges with tiny spiniform setae in distal $2 / 3$ (Fig. 1E).

Third pereopod (Fig. 3H) slender, same length as second pereopod; coxa with median spine (except in female NHMW 25675), with gonopore in females; carpus half as long as merus; propodus 0.8 times

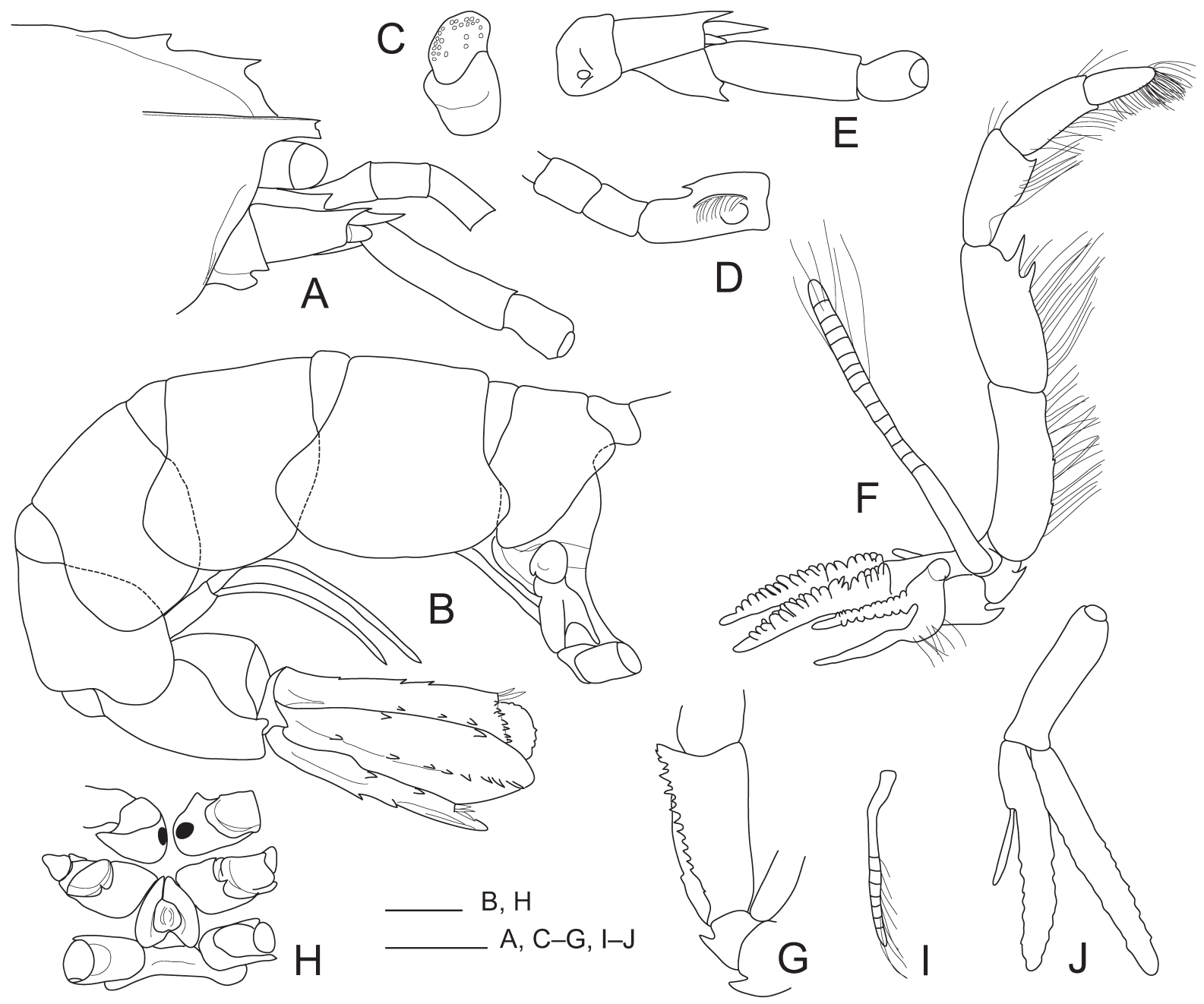

Fig. 2. Montanaxius mediumquod gen. et sp. nov., paratype,, , NHMW 25675. A. Front in lateral view (rostrum broken). B. Pleon in lateral view. C. Left eyestalk, dorsal view. D. Right antennule in mesial view. E. Right antenna in ventral view. F. Third maxilliped in lateral view. G. Same in mesial view. H. Sternites 6-8. I. Left first pleopod in lateral view. J. Right second pleopod in posterior view. All setation omitted except in F and I. Scale bars: $1 \mathrm{~mm}$. 


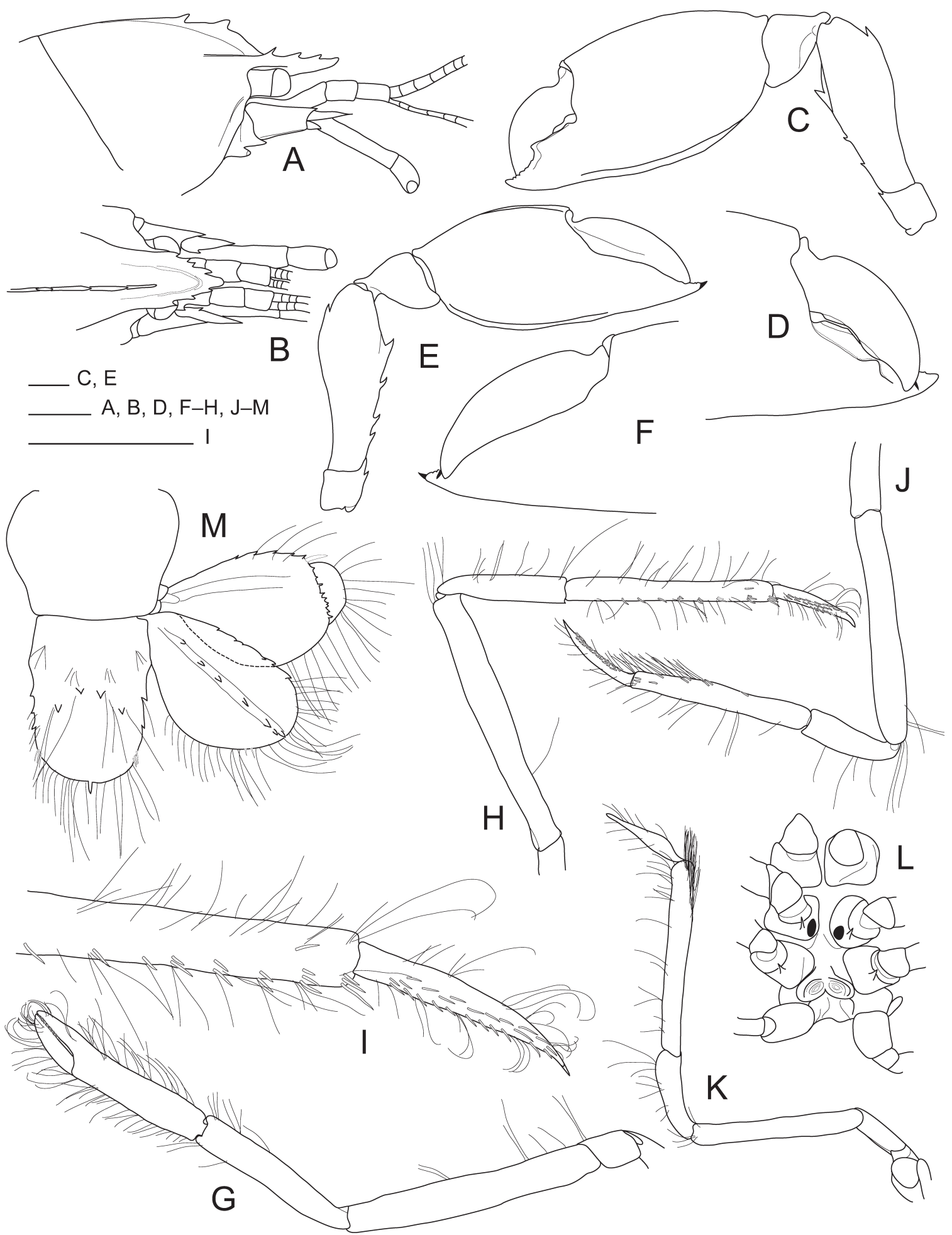

Fig. 3. Montanaxius mediumquod gen. et sp. nov., paratype,, , NHMW 25676. A. Front in lateral view. B. Same in dorsal view. C. Major cheliped in lateral view. D. Same, fingers in mesial view. E. Minor cheliped in lateral view. F. Same, fingers in mesial view. G. Second pereopod, lateral view. H. Third pereopod, lateral view. I. Same, detail of distal articles. J. Fourth pereopod in lateral view. K. Fifth pereopod in lateral view. L. Sternites $6-8$ in ventral view. M. Telson and right uropods, dorsal view. Setation omitted in A-F. Scale bars: $1 \mathrm{~mm}$. 

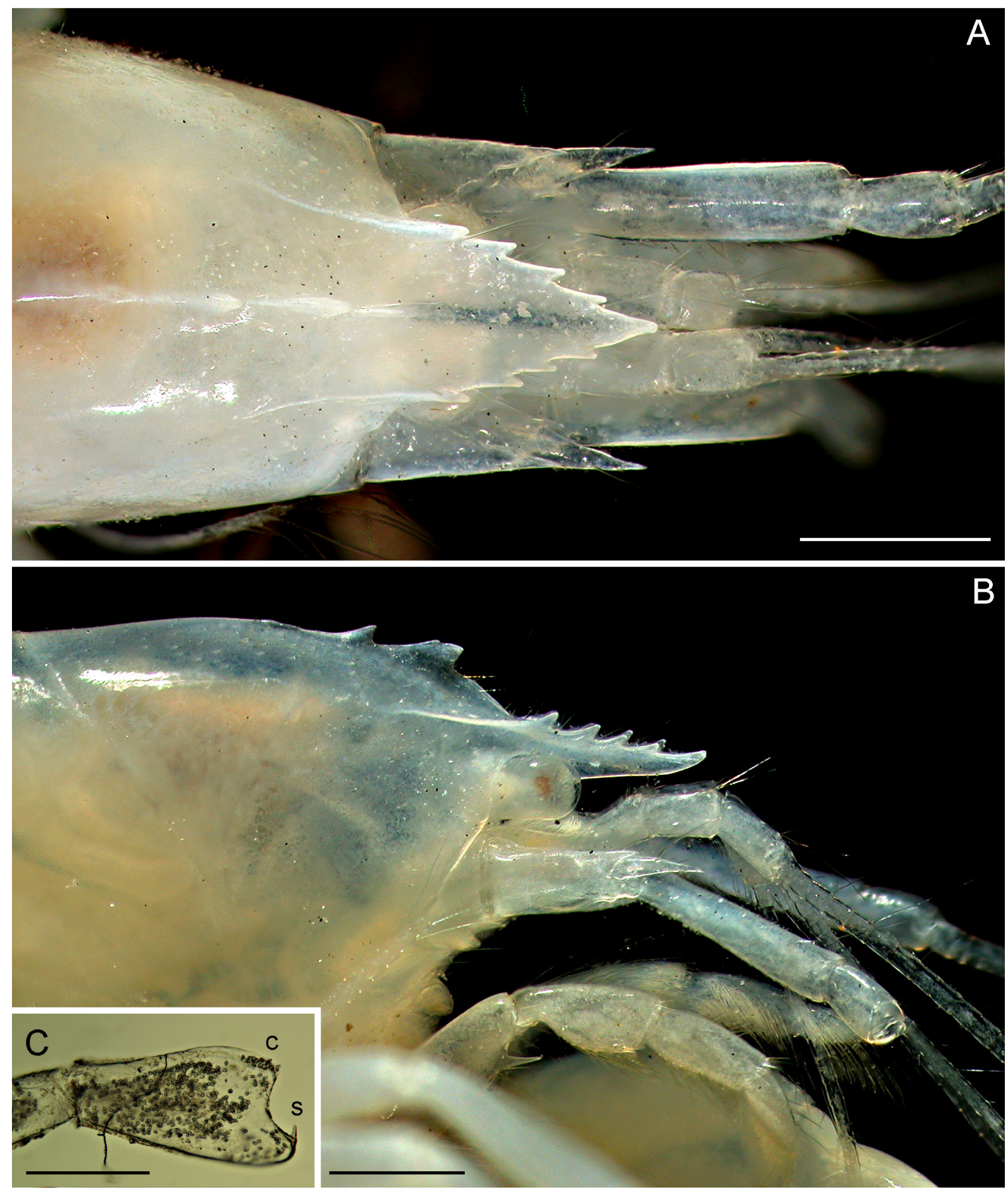

Fig. 4. Montanaxius mediumquod gen. et sp. nov., holotype, ð, NHMW 25677. A. Front in dorsal view. B. Same in lateral view. C. Terminus of left first pleopod, posterior view. Abbreviations: $\mathrm{c}=$ cincinnuli (appendix interna); $\mathrm{s}=$ spine. Scale bars: $\mathrm{A}-\mathrm{B}=1 \mathrm{~mm} ; \mathrm{C}=500 \mu \mathrm{m}$. 
Table 1. Gill formula of Montaxius mediumquod gen.et sp. nov.; $r=$ rudimentary.

\begin{tabular}{lccc|ccccc}
\hline & \multicolumn{7}{c}{ thoracic somites } \\
\hline & 1 & $\begin{array}{c}2 \\
\text { maxillipeds }\end{array}$ & 3 & 4 & 5 & 6 & 7 & 8 \\
& & 2 & 3 & 1 & 2 & 3 & 4 & 5 \\
pleurobranch & 1 & 0 & 0 & 0 & 1 & 1 & 1 & 0 \\
arthrobranch & 0 & $\mathrm{r}$ & 2 & 2 & 2 & 2 & 2 & 0 \\
podobranch & 0 & $\mathrm{r}$ & 1 & 1 & 1 & 1 & 0 & 0 \\
epipod & 1 & 1 & 1 & 1 & 1 & 1 & 1 & 0 \\
exopods & 1 & 1 & 1 & 0 & 0 & 0 & 0 & 0 \\
\hline
\end{tabular}

length of merus, with group of spiniform setae on lateral face distally; dactylus 0.4 times length of propodus, tapering to corneous tip, with row of spiniform setae on lateral face (Fig. 3I).

Fourth pereopod (Fig. 3J) slender, same length and article proportions as third pereopod; coxa with median spine; propodus with dense setae on lower border distally, lateral face with spinifrom setae, dactylus with rows of spiniform setae.

Fifth pereopod (Fig. 3K) slender, same length as P2-P4, precoxal lobe ovate, with small acute spine ventrally, coxa with small gonopore in male (Fig. 1F), small round plate laterally (Fig. 1G); merus 3 times as long as ischium; carpus as long as ischium; propodus twice as long as carpus, with dense stiff setae on lower border distally; dactylus as long as ischium, tear-shaped.

Epipods on Mxp1 to P4, podobranchs on Mxp2 (rudimentary) to P3, arthrobranchs on Mxp2 (rudimentary) to P4, pleurobranchs above P2-P4 (see Table 1).

Gonochoristic. Male first pleopod (Figs 1G-I, 4C) uniramous, two-articled; second article half as long as first, with indentation distally, lateral lobe with mesially directed spine, mesial lobe with cincinnuli (appendix interna). Second male pleopod (Fig. 1J-K) with appendix masculina and appendix interna of about the same length. Female first pleopod (Fig. 2I) uniramous, flagellate distally. Female second pleopod (Fig. 2J) with appendix interna. Third to fifth pleopods slender, with appendix interna, one third length of endopod.

Telson longer than wide, posterior margin with median spine, lateral edges with two to three spines at midlength and group of three spiniform setae proximally, two pairs of spines on dorsal surface. Uropodal endopod with curved posterior border and straight anterior border, median row of spines on dorsal surface. Uropodal exopod with spines distally on anterior border, one to two strong spiniform setae at transition to transverse suture, the latter distally beset with spines, posterior border smooth (Fig. 3M).

\section{Colour}

Body and appendages translucent, brownish, chelipeds brown, cornea light brown, reflective (after photograph in Stone 2012).

\section{Ecology}

The shrimps were associated with an unidentified hexactinellid sponge. 


\section{Distribution}

Known only from the type locality: southwestern Indian Ocean, seamount 'Middle of What', $37^{\circ} 57.915^{\prime} \mathrm{S}, 50^{\circ} 24.426^{\prime} \mathrm{E}, 1135 \mathrm{~m}$ depth.

\section{Discussion}

As the new species is gonochoristic, it clearly does not belong to the calocaridid group of axiid genera because hermaphroditism is a feature of all species of this group (Kensley 1989; Sakai 2011). In addition, the new species lacks the terminal enlarged appendix masculina on male Plp2 that is characteristic for the calocaridid group (Poore 1994).

When using the key in Sakai \& de Saint Laurent (1989), the new species keys to the genus Dorphinaxius Sakai \& de Saint Laurent, 1989. The only species of this genus, Dorphinaxius kermadecensis (Chilton, 1911) [senior synonym of $D$. appendiculis (Poore \& Griffin, 1979)], differs from the new species by having a much shorter rostrum with no other lateral spines than the prominent supraocular spines (vs long rostrum with several lateral spines without supraocular spines), the presence of a submedian carina (vs absence), the absence of male Plp1 (vs presence) and the lack of a median telson spine (vs presence).

In the key to Axiidae of Poore (1994) the new species keys out to the genus Spongiaxius Sakai \& de Saint Laurent, 1989. The only species of this genus, Spongiaxius brucei (Sakai, 1986), differs from the new species by the typical shape of its rostrum with erect spines, separated by a constriction from the carapace (vs rostrum continuous with carapace), the presence of a toothed submedian carina (vs absent submedian carina), acute pleomere pleura (vs rounded pleura) and a distinctive massive dactylus in the major cheliped (Poore \& Collins 2009).

The key to Axiidae of Sakai (2011) leads to the monotypic genus Levantocaris Galil \& Clark, 1993. The new species shows some similarities with Levantocaris hornungae Galil \& Clark, 1993 in lacking the submedian carina and having rounded pleomere pleura, but differs by having a strongly elevated gastric region with a toothed median carina (vs slightly convex gastric region with unarmed median carina), fully pigmented, rounded eyes (vs weakly pigmented, anteriorly flattened eyes). Planaxius Komai \& Tachikawa, 2008, a genus containing only the type species P. brevifrons Komai \& Tachikawa, 2008, is also similar to the new genus, especially in the lack of a submedian carina on the anterior part of the carapace, a similar rostrum and a short lateral carina (Komai \& Tachikawa 2008; Poore \& Collins 2009). Planaxius was described originally as lacking a median carina. Poore \& Collins (2009), however, reported that their individual from Australia referred to this species has a definite median gastric carina at the base of the rostrum extending as far back as the lateral gastric carinae. Nevertheless, the new genus can be differentiated from Planaxius by the presence of a prominent median toothed carina on the anterior carapace, the lack of supraocular spines on the carapace and the presence of a median telson spine. In addition the new species has a first male pleopod with mesially directed spine and appendix interna, not found in any other genus of the Axiidae. In summary, a new genus is warranted.

\section{Acknowledgements}

The author thanks Sammy De Grave (Oxford University Museum of Natural History) for making this interesting specimen from the southwest Indian Ocean seamounts available for study. My thanks are extended to the crew and scientists of NERC cruise 'James Cook' JC066 on the SW Indian Ridge. The collection of these specimens was funded through NERC Grant NE/F005504/1, PI A.D. Rogers. This project was part of the Southwest Indian Ocean Seamounts Project, supported by the EAF Nansen Project, the Food and Agriculture Organization of the United Nations, the Global Environment Facility and the International Union for the Conservation of Nature. The manuscript benefited greatly from the comments of two anonymous referees. 


\section{References}

Coleman C.O. 2003. "Digital inking": how to make perfect line drawings on computers. Organisms Diversity \& Evolution 3: 303-304. http://dx.doi.org/10.1078/1439-6092-00081

Coleman C.O. 2009. Drawing setae the digital way. Zoosystematics and Evolution 85 (2): 305-310. http://dx.doi.org/10.1002/zoos.200900008

Haug C., Mayer G., Kutschera V., Waloszek D., Maas A. \& Haug J.T. 2011. Imaging and documenting gammarideans. International Journal of Zoology article ID 380829: 1-9. http://dx.doi. org $/ 10.1155 / 2011 / 380829$

IUCN 2013. Seamounts Project. An Ecosystem Approach to Management of Seamounts in the Southern Indian Ocean. International Union for Conservation of Nature and Natural Resources, Gland, Switzerland. Available from http://www.undp.org/content/dam/undp/library/Environment $\% 20$ and $\% 20$ Energy/Water\%20and\%20Ocean\%20Governance/Seamounts_Project.pdf [accessed 19 Feb. 2016]

Kensley B. 1989. New genera in the thalassinidean families Calocarididae and Axiidae (Crustacea, Decapoda). Proceedings of the Biological Society of Washington 102 (4): 960-967. Available from http://biodiversitylibrary.org/page/34551350 [accessed 9 Feb. 2016]

Komai T. 2013. A new species of the hippolytid genus Paralebbeus Bruce \& Chace, 1986 (Crustacea: Decapoda: Caridea) from the Coral Seamount, southwestern Indian Ocean. Zootaxa 3646 (2): 171-179. http://dx.doi.org/10.11646/zootaxa.3646.2.5

Komai T. \& Tachikawa H. 2008. Thalassinidean shrimps (Crustacea: Decapoda) from the Ogasawara Islands, Japan. Natural History Research 10 (1): 19-52. Available from http://www.chiba-muse.or.jp/ NATURAL/publication/nhr_10-1_4komai.pdf [accessed 19 Feb. 2016]

Komai T., De Grave S. \& Saito T. 2016. Two new species of the stenopodidean shrimp genus Spongiocaris Bruce \& Baba, 1973 (Crustacea: Decapoda: Spongicolidae) from the Indo-West Pacific. Zootaxa 4111 (4): 421-447. http://dx.doi.org/10.11646/zootaxa.4111.4.5

Poore G.C.B. 1994. A phylogeny of the families of Thalassinidea (Crustacea: Decapoda) with keys to families and genera. Memoirs of the Museum of Victoria 54: 79-120. Available from http:// biodiversitylibrary.org/page/39767522 [accessed 9 Feb. 2016]

Poore G.C.B. 1997. A review of the thalassinidean families Callianideidae Kossmann, Micheleidae Sakai, and Thomassiniidae de Saint Laurent (Crustacea, Decapoda) with descriptions of fifteen new species. Zoosystema 19 (2-3): 345-420.

Poore G.C.B. \& Collins D.J. 2009. Australian Axiidae (Crustacea: Decapoda: Axiidea). Memoirs of Museum Victoria 66 (2): 221-287. Available from http://museumvictoria.com.au/pages/13541/b221287_MMV66_PooreCollins_F.pdf [accessed 19 Feb. 2016]

Rogers A.D. \& Taylor M.L. 2012. Benthic biodiversity of seamounts in the southwest Indian Ocean. Cruise report - R/V James Cook 066. Southwest Indian Ocean Seamounts expedition - November 7th - December 21st, 2011, 235 pp. Available from http://iwlearn.net/iw-projects/1462/reports/cruisereports/asclme-benthic-biodiversity-of-seamounts-in-the-southwest-indian-ocean-cruise-report-1/at download/file [accessed 3 Aug. 2015]

Sakai K. 2011. Axioidea of the World and a reconsideration of the Callianassoidea (Decapoda, Thalassinidea, Callianassida). Crustaceana Monographs 13: 1-616.

Sakai K. \& Saint Laurent M de. 1989. A check list of Axiidae (Decapoda, Crustacea, Thalassinidea, Anomula), with remarks and in addition descriptions of one new subfamily, eleven new genera and two new species. Naturalists, Publications of Tokushima Biological Laboratory, Shikoku University 3: 1-104. 
Stone G.S. 2012. Mountains in the Sea. National Geographic 2012 (September): 67-77. Available from http://ngm.nationalgeographic.com/2012/09/seamounts/stone-text [Accessed 19 Feb. 2016]

Manuscript received: 29 February 2016

Manuscript accepted: 12 April 2016

Published on: 13 September 2016

Topic editor: Rudy Jocqué

Desk editor: Kristiaan Hoedemakers

Printed versions of all papers are also deposited in the libraries of the institutes that are members of the EJT consortium: Muséum national d'Histoire naturelle, Paris, France; Botanic Garden Meise, Belgium; Royal Museum for Central Africa, Tervuren, Belgium; Natural History Museum, London, United Kingdom; Royal Belgian Institute of Natural Sciences, Brussels, Belgium; Natural History Museum of Denmark, Copenhagen, Denmark; Naturalis Biodiversity Center, Leiden, the Netherlands. 